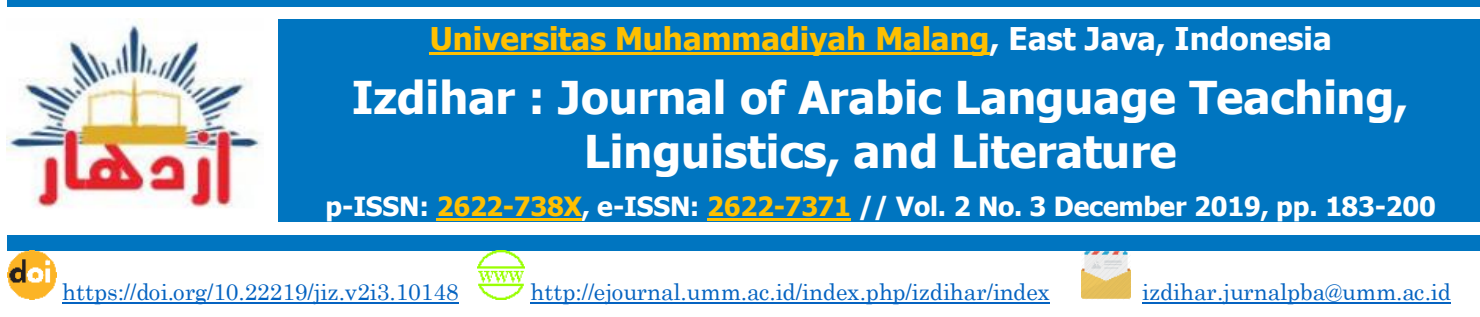

\title{
Interrogative Sentence: A Contrastive Study of Arabic and Indonesia
}

\author{
Khoirin Nikmah \\ Universitas Muhammadiyah Yogyakarta, Indonesia \\ khoirinikmah@gmail.com
}

ARTICLE INFO

Article History:

Received: 01/11/2019

Revised: $15 / 1 / 2020$

Accepted: $18 / 1 / 2020$

Published: $26 / 1 / 2020$

\section{Keyword}

\section{ABSTRACT}

Involving first language (L1) in second language learning (L2) is considered as an effective method to be practiced. This research focuses on a contrastive study between Arabic and Indonesian. It aims to investigate similarities and differences of the two languages, especially about their interrogative sentence forms. It is descriptive qualitative research which applies two methods; observation and introspection method. Then, Contrastive Analysis (CA) is used to analyze the data. The result shows that similarity concept between Arabic and Indonesian is many shown on matā, ayna, limādzā, and hal. Meanwhile, differences between both of them are shown on $m \bar{a}$, man, ayy, and kayfa. As a result, it may occur errors in the use of question, errors in translating interrogative sentence, and errors in understanding question.

\section{Copyright (c) 2019, Nikmah} This is an open access article under the CC-BY-SA license

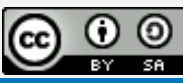

Contrastive Analysis; Interrogative Sentence; Second Language Learning

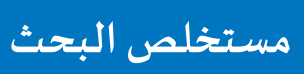

تضمّن اللغة الأولى في تعلّم اللغة الثانية فهو اعتبر كالطريقة التأثيرة للتطبيق. و يبحث هذا البحث عن دراسـة المقارنة بين اللغة العربيّة و الإندونيسيّة و لذالك كان الأغراض فمنهم تحليل المتساويات و التمييزات بين لغتان، وبالخصوص في في كلمات الإستفهام. و إنّه بحث وصفيّ كيفيّ الذي استعمل طريقتان، يعني طريقة الملاحظة و الاستبطانيّة. و بعد ذلك استعمل تحليل المقارنة ليبحث البيانات. و الاستنتاج يدلّ على أنّ المتساويات بين اللغة العربيّة و الإندونيسيّة وجودهم في جملة الإستفهام "متى و أين و لماذا و هل". أمّا التمييزات عند لغتان يتضمّمن جملة الإستفهام "ما و مَن و أيّّ و كيفيّ". و في النهاية أنّ التمييزات يسبّب إلى وجود بعض المشكلات، كمثل أخطاء عند يجعل كلمات الإستفهام و أخطاء عند يترجم كلمات الإستفهام و أخطاء عند يفهم الأسئلة.

$$
\text { كلمات أسـاسية تحليل المقارنة؛ كلمات الاستفهام؛ تعلّم اللغة الثانية }
$$
}




\section{INTRODUCTION}

Arabic is a language spoken by Arab communities in Middle East, North Africa, and the Arab World. Arabic also has been admitted as one of the official languages by the United Nations. Enein (n.d., p. 1) mentions that according to the United Nations Organization Library, over 200 million people in 22 different countries use Arabic as their first and official language. It makes Arabic the 6th most widely spoken language in the world. Furthermore, on the 18th of December 1973, Arabic became one of the six official languages of the United Nations along with English, Chinese, French, Spanish, and Russian. In addition, there are significant Arabic speaking communities in countries like Tanzania, Uganda, Nigeria, and the horn of Africa. There are Arabic speaking communities in the US, Europe, and in Asia, especially in Indonesia and Malaysia. According to Masqon (2018, p. 34) Arabic is a language of thought, culture, moral, religion, and al-Quran al karim. While Firdaus $(2019$, p. 36) said that Arabic is one of languages that have long different history. Therefore Rabab'ah \& Bulut (2007, p. 83) reveal that Arab culture and Islam are two of reasons why thousands of nonnative speakers of Arabic from all over the world want to learn Arabic as a foreign language. One of effective media to learn Arabic is Holy Quran. Nikmah (2019, p. 79) says that learning Arabic by Holy Quran is not only learning a language but also the content, because it is way of life for every moslem.

Arabic is divided into three types; classical Arabic, standard Arabic, and spoken Arabic. Owens (2006) explains that classical Arabic is usually referred to the language used before Islam, language of poetry, literature, and golden ages of Islam and Arabic sciences. Later on, after nearly, the European Renaissance, a new age appeared along with a new version of Arabic has been called Standard Arabic or sometimes as Modern Standard Arabic. More importantly, what has been called as Classical Arabic is being only used for the Holy Quran and ancient Arabic books. Then, Standard Arabic is being only used for official states, academic writings, school materials, news, and broadcasting (Momani \& Al Taheer, 2015, p. 3). In Arabic, spoken Arabic can be called as 'amiyah. According to Qodri (2019, p. 5) 'amiyah is different with fusha (standard Arabic). The differences are including words and also sentences.

Bassiouney (2009) reveals that fușha is used in writing and orally for formal functions, such as religious, educational, and other cultural events. In its written form, it is used almost exclusively in any printed publication all over the world. In its oral form, it is used in formal situations, ranging from radio news broadcasts to university lectures to political speeches to mosque or church sermons or such other formal addresses as those at national or international conferences. While 'Ammiyya does not have a script and is not officially written. It is used in 
casual speech for usual day-to-day activities in such informal settings as home, work, social gatherings, and conversations on the street as well as in all other contexts that do not demand the use of fușha (Brosh, 2019, p. 353). Fatoni (2019, p. 140) classify Arabic lesson into four types such as Arabic for academic purposes, Arabic for businessmen people, Arabic for education people, and Arabic for objective purposes.

As a foreign language, Arabic has a big enough role to Indonesian language blooming. Many of Indonesian vocabularies are absorbed from Arabic, not only about Islamic field but also various fields. In addition, two languages coming from two different language families can have both differences and similarities. This gives advantages and disadvantages to the language learners of one of the two languages. According to Keraf (1984, p. 25), Arabic is an Afro-Asiatic within the Semitic language subgroup. Meanwhile, Indonesian belongs to Austronesian language family. In this regard, a different language family results differences not only in the alphabet system, but also micro linguistic and macro linguistic levels. However, the method to accelerate the understanding in learning a foreign language is taking advantage of learner's mother language. Contrastive analysis can be a tool to facilitate language learners to understand $L 2$ by comparing it with L1.

The comparison between mother tongue and foreign language is the key of ease and difficulty in foreign language learning. Fries (Lado, 1957, p. 1-2) assumed that individuals tend to transfer and distribute the forms and meanings from the native language and culture to the foreign language and culture, both when attempting to speak the language, to act in the culture, and to understand the language and culture as practiced by the native speakers. Omar (2017, p. 159) mentions that culture plays an important role in boosting the linguistic abilities of learners of a second language. El Majid \& Ahmed (2016, p. 132) said that learners usually face some certain problems in the translation process such as ambiguous terms, due to cultural variety, and problems that originate from structural and lexical differences between languages and multiword units. Additional problematic area would be the grammar because there are several differences between Arabic and Indonesian.

In language transfer process, the existence of language errors is certainly understandable. Therefore, a special approach is needed to overcome language errors and other problems in second language learning. There are four types of approaches introduced by Hakuta and Cancino (Els, T. V. et al, 1991). They are Contrastive Analysis (CA), error analysis, performance analysis, and discourse analysis. This research focuses on CA to compare the similarities and differences of interrogative sentence between Arabic and Indonesian. 
CA is one of linguistics field studying about language comparison. Therefore, it is also called as contrastive linguistics. The study of CA involves source language and target language. Source language is a mother tongue or first language (L1). Meanwhile, target language is a foreign language or second language (L2). Basically, CA is like a tool aims to identify similarities and differences between L1 and L2. Therefore, the difficulty in mastering certain structures in a second language depends on the difference between the learner's mother language and the language they were trying to learn (Rustipa, 2011, p. 17). Meanwhile, Parera (1997, p. 111) describes CA based on four areas; phonology, morphology, syntax, and semantic level. Dost (2017, p. 34) said that there were four components of contrastive analysis procedure: 1) Taking the two languages, L1 and L2, and writing formal descriptions of them, 2) picking forms from descriptions for the contrast, 3) making a contrast of forms chosen, 4) making a prediction of difficulty through the contrast.

The basic rationale for conducting $\mathrm{CA}$ is the phenomenon of language interference or language transfer. CA studies enable to compare two languages in order to predict the difficulties the students may encounter. The difficulties are chiefly due to the differences between the two languages (Fauziati, 2014, p. 18). In this regard, in second language learning, language error cannot be avoided. Sabbah $(2015$, p. 270$)$ said that where the first and second language rules are not the same, errors are likely to occur as a result of interference between the two languages. Adila (2019, p. 33) said that errors are an unacceptable use of linguistic item from the perspective of a native speaker or fluent of a language.

In language learning process, Hasan (2018, p. 105) explained that language progress is very depending on two factors; 1 ) how many differences and similarities between $L 1$ and $L 2,2$ ) how far students give impact toward Arabic learning process. However, transfer and interference are two concepts which relate to successful and difficult learning. Transfer is a language learning process from L1 to L2. Then, interference is like an error caused by incorrect language transfer process. While language usage from $L 1$ to $L 2$ which inacceptable is called as interference (Parera, 1997, p. 121). However, there is a critic about transfer and interference concept. Smith (1983), Kellerman (1984), and some European linguists of CA propose 'cross linguistic influence' as the concept heading of learning language process. Therefore, cross linguistic are including; transfer, interference, borrowing, code switching, code mixing, and language process (Parera, 1997, p. 122).

Basically, the term language transfer can be considered as an important part in language learning. It is divided into two categories; positive transfer and negative transfer. Positive transfer indicates that learners understand L2, they can product correct word or structure in L2. On the contrary, negative transfer 
can be caused by differences concept between $L 1$ and $L 2$. Khansir (2012, p. 1028) mentions that negative transfer happens when the forms of the target language and those of the learner's mother tongue are different from each other, whereas, the positive transfer between the mother tongue and the target language is similar. Al Khresheh (2016, p. 333) explains four types of divergences which are caused by the two language differences. First, overproduction, learners produce a given $L 2$ structure with much greater occurrence than natives of $L 2$ do. Second, underproduction, learners produce hardly any or no examples of $L 2$ structure. Third, misinterpretation, this type of error occurs when L1 structures influence L2 messages interpretation. Fourth, production, this type of errors can be classified into six categories, such as; substitutions, calques, underdifferentiation, over-differentiation, hypercorrection, and alteration of structures.

According to Rustipa (2011, p. 17), the goals of CA can be stated as follows; to make foreign language teaching more effective, to find out the differences between the first language and the target language based on the assumptions that foreign language learning is based on the mother tongue, positive transfer, and negative transfer. By contrastive analysis, problems can be predicted and considered in the curriculum.

There are four advantages of CA such as; 1 ) CA may show differences and similarities between $L 1$ and $L 2,2$ ) contrastive approach may explain culture differences between the two languages, 3) the result of CA has benefit for foreign language teaching, designing materials, and predicting error performance in language, 4) the result of CA is like a contribution from translation field (Nur, 2016, p. 67). CA is supposed to enable educators to spot areas of difficulty arising from differences between the mother tongue (L1) and L2 (Al Ajlouny, 2007, p. 152).

Previous Research about CA involving Arabic has ever been published by Saidah (2011). Her research is about 'Contrastive Analysis between Adawat al Istifham in Arabic and Question Words in English'. Saidah (2011, p. 116) concludes that question words in Arabic are divided into word (harf) and noun (isim). Meanwhile, English has noun, pronoun, adjective, adverb, and conjunction as question words. Then, interrogative sentences in Arabic not requires 'to be', in other hand, English use it. Both Arabic and English put their question words in some different positions. Then, research by Huda (2019) is 'A Comparative Study of Object Structure between Arabic and Indonesian'. The research concludes that differences between Arabic and Indonesian is showed on object position. In Arabic, object can be put before the subject and verb. However, it cannot to be applied in Indonesian, because object is always put after subject and verb.

There is no previous research focuses on CA of interrogative sentence between Arabic and Indonesian. According to Lindawati (2016, p. 349), basically, 
study of Indonesian interrogative sentences requires the researcher to explore how sentences are constructed and how they are used by speakers of Indonesian in actual communication. Therefore, this research use introspection method with language knowledge of researcher as an Indonesian native.

This research aims to compare between similarities and differences of question forms of Indonesian and Arabic, including ' $m \bar{a}$, man, ayy, kayfa, matā, ayna, limādzā, and hal'. The solution proposed here addresses the problems and answers two questions; Firstly, similarities and differences between them due to their meanings and structures. Secondly, some prediction problems in making interrogative sentence involving both of the two language.

\section{METHOD}

This descriptive qualitative research applies two methods; Firstly, observation method with tapping technique. Basically, the term tapping is not only related to spoken texts, but also written ones. In this case, the first data is taken from 'Arabiyyah Baina Yadaik 1 by Al Fauzan, A.I., Husain, M.T., Fadhil, M.A.K.M. (2003) involving Arabic interrogative sentences and also interview with Arabic native. Secondly, introspection method. This method involves researcher as a native language. Therefore, the second data is Indonesian interrogative sentences obtained from language knowledge of researcher as an Indonesian native.

Then, Contrastive Analysis (CA) is used as a tool to analyze the collected data. Researcher compares between the two languages to find similarities and differences between them. Afterwards, researcher predicts some problems may occur of interrogative sentence as a result of its differences.

\section{FINDINGS \& DISCUSSION}

\section{Interrogative Sentence Forms and Functions}

Lindawati (2016, p. 348) explains that the term of interrogative sentence results categorization based on meaning. In this case, sentences can be classified into declarative, command, question, exclamation, and emphatic ones. Then, interrogative sentence has main function to ask about someone or something. According to Umami (2015, p. 153), questions create anticipation, arouse interest, challenge the reader into thinking about the topic of the text, and have a direct appeal in bringing the second person into a kind of dialogue with the writer, which other rhetorical devices do not have to the same extent. 
Contrastive linguistics is the door to understand languages based on their similarities and differences. However, each language has different characteristics in meaning. Selection of words to translate L1 into L2 will be different if it is associated with lexical or grammatical meanings. Look at table 1.

\begin{tabular}{|c|c|c|c|c|c|}
\hline No & Indonesian & Arabic & No & Indonesian & Arabic \\
\hline 1 & Apa? & مَا؟ [mā] & 7 & Di mana? & [أَيْنَ؟ [ayna] \\
\hline 2 & Apa? & مَاذَا؟ [mādzā] & 8 & Kapan? & [mata] \\
\hline 3 & $\begin{array}{c}\text { Apa? / } \\
\text { dengan apa? }\end{array}$ & [bima] بِهَ؟؟ & 9 & Mengapa? & [ [لمَاذَا؟ [imādzā] \\
\hline 4 & Apakah? & [ha/ هَلْ؟؟ & 10 & Bagaimana? & كَيْفَ؟ [kayfa] \\
\hline 5 & Yang mana? & [ayyu] [أي؟؟ & 11 & Berapa? & كَمْ؟ [kam] \\
\hline 6 & Siapa? & [ مَنْ؟ & 12 & Berapa? & بَكَمْ؟ [bikam] \\
\hline
\end{tabular}

From the table 1, it can be explained when the Arabic question words are translated into Indonesian, some have fixed meanings either when standing alone or when connected with other words. The question words with the constant

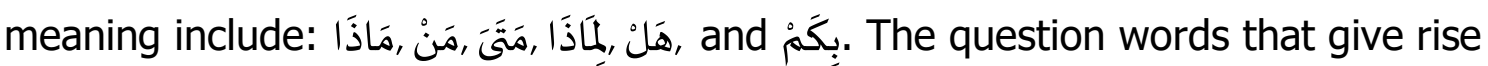

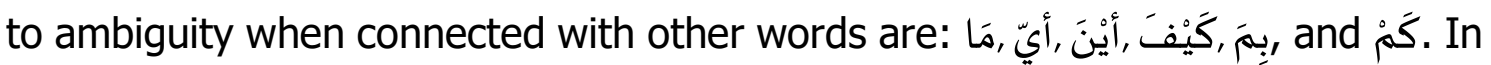
addition, the grammatical construction of the interrogative sentence in Arabic is different from Indonesian. Question words in Arabic are always placed at the beginning of the sentence, while the position of the question words in Indonesian can be at the beginning, middle, or end of the sentence.

Some of questions between Arabic and Indonesian has different meaning caused not only structure, but also its language habit. Lado (1957, p. 58) said that in practical terms, the use of a grammatical structure by a speaker depends on habit. The average speaker of a language has from early childhood reduced practically all the operation of his grammatical system to habit. The table 2 is a comparison between Arabic and Indonesian interrogative sentences.

Table 2. List of abbreviations

\begin{tabular}{lll}
\hline No & CA & Contrastive Analysis \\
\hline 1 & V & Verb \\
\hline 2 & N & Noun \\
\hline 3 & PP & Personal Pronoun \\
\hline 4 & PoP & Possessive Pronoun \\
\hline 5 & DP & Demonstrative Pronoun
\end{tabular}

\begin{tabular}{lll}
\hline No & CA & Contrastive Analysis \\
\hline 6 & Adv & Adverb \\
\hline 7 & Prep & Preposition \\
\hline 8 & Part & Particle \\
\hline 9 & Aux & Auxiliary \\
\hline
\end{tabular}


Mā, Mādzā, Bima (مَا، مَاذَا، بَِ)

The interrogative sentences which use question word as 'bi ma, ma, madzd' is often associated with the meaning of 'apa' in Indonesian. According to Al Ghalayaini (2009, p. 107), ' $m a$ ' and ' $m \bar{a} d z a$ ' as a question word is used to ask something not human, animals, plants, something not alive, activity, reality, and characteristic. Meanwhile, in Kamus Besar Bahasa Indonesia (KBBI), the word 'apa' has functions to ask a name (not for person), type, quality, and news. In some structures, the question word ' $m \bar{d}$ ' may occur ambiguity in translation into Indonesian. It can be translated as 'apa', 'apakah', 'siapa', 'berapa', 'di mana', or 'bagaimana'. However, the word 'mádza' has constant meaning as 'apa'. Meanwhile, the word 'bi ma' can be meant 'apa' or 'bagaimana'. The selection meaning in Indonesian depends on by what the question word is followed.

Table 3. Interrogative sentences of 'Mā, Mādzā, Bima'

\begin{tabular}{|c|c|c|c|c|}
\hline No & Arabic & Structure & Indonesian & Structure \\
\hline 1. & مَا هَذَا؟ & مَ + DP & Apa ini? & Apa + DP \\
\hline 2. & مَا هِوَايَتُك؟ ؟ & L + PoP & Apa hobimu? & Apa + PoP \\
\hline 3. & مَا مَعْنَى فَلْسَفَفَة؟ & مَا $+N$ & Apa arti filsafat? & Apa $+\mathrm{N}$ \\
\hline 4. & 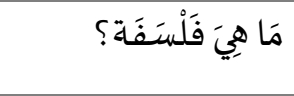 & مَ + PP & $\begin{array}{l}\text { Apakah/ Apa yang dimaksud } \\
\text { dengan filsafat? }\end{array}$ & $\begin{array}{l}\text { Apakah/ Apa } \\
\text { + Part. }\end{array}$ \\
\hline 5. & مَاساسْمُكَك؟ & مَ + PoP & $\begin{array}{l}\text { Siapa namamu? } \\
\text { (because it refers to person's } \\
\text { name) }\end{array}$ & Siapa + PoP \\
\hline 6. & مَا التَّارِيخ الآن؟ & مَا N N N & $\begin{array}{l}\text { Tanggal berapa sekarang? } \\
\text { (because it refers to number) }\end{array}$ & $\mathrm{N}+$ berapa \\
\hline 7. & مَا وَزْنُ زَيْنَبُ ؟ & مَ $+N$ & $\begin{array}{l}\text { Berapa berat badan Zainab? } \\
\text { (because it refers to number) }\end{array}$ & Berapa + N \\
\hline 8. & مَا رَقْمُمُ بَيْتك؟ & مَا N N N & $\begin{array}{l}\text { Berapa nomor rumahmu? } \\
\text { (because it refers to number) }\end{array}$ & Berapa + N \\
\hline 9. & مَا عُنْوَانَكُ؟؟ & مَ + PoP & $\begin{array}{l}\text { Di mana alamatmu? } \\
\text { (because it refers to place) }\end{array}$ & $\begin{array}{l}\text { Di mana + } \\
\text { PoP }\end{array}$ \\
\hline 10. & مَا رَأْيُكَ عَنَ هَذَا & مَ + PoP & $\begin{array}{l}\text { Bagaimana pendapatmu } \\
\text { tentang rumah ini? } \\
\text { (because it refers to opinion) }\end{array}$ & $\begin{array}{l}\text { Bagaimana }+ \\
\text { PoP }\end{array}$ \\
\hline 11. & مَاذَا تَقَرَأُ & مَاذًا + V & Apa yang kamu baca? & $\begin{array}{l}\text { Apa + Part. } \\
+ \text { PP + V }\end{array}$ \\
\hline 12. & ماذا تَأُكُل؟ & مَاذًا + V & Apa yang kamu makan? & $\begin{array}{l}\text { Apa + Part. } \\
+ \text { PP + V }\end{array}$ \\
\hline 13. & بِنَ نَصَحَكَ الطُبَّبِ؟ & U بِنَ V V & $\begin{array}{l}\text { Apa/ Bagaimana nasehat } \\
\text { dokter? }\end{array}$ & Apa + N \\
\hline 14. & بِمَ تَشْعُرُ في مككة؟ & + بِمَ V V & $\begin{array}{l}\text { Bagaimana perasaanmu berada } \\
\text { di Makkah? } \\
\text { (because it refers to opinion } \\
\text { about feeling) }\end{array}$ & $\begin{array}{l}\text { Bagaimana }+ \\
\text { PoP }\end{array}$ \\
\hline
\end{tabular}


Based on table 3, the data (1), (2), and (3) have similarity in meaning and structure. The word ' $m \vec{a}$ or 'apa' can be followed by DP/ PoP/ N. Meanwhile, data $(5),(6),(7),(8),(9)$, and (10) have similarity in structure but different in meaning. The word ' $m \nexists \exists$ have many different meanings, such as: 'siapa', 'berapa', 'dimana', and 'bagaimana'. Those meaning selections depend on the following word. Then, data (4), (11), (12), (13), (14) have different structure. The word 'mādză' and 'bima' can be followed by verb directly because Arabic verb has agglutinative PP. In addition, 'mādzā' and 'bima' not require participle before verb. However, in Indonesian, the word 'apa' must be followed by participle before $\mathrm{PP}, \mathrm{N}$, and PoP.

\section{Ayy, Fì Ayy, Min Ayy (أيّ، في أيّ، مِنْ أَيّ)}

The question words (أيّ، في أيّ، مِنْ أَيِّ (ائي ) are used to ask for an explanation about something. In the Indonesian translation, أيّ means 'yang mana', 'apa', 'berapa', and 'dari mana'. In KBBI, the question 'yang mana' is used to ask about one of people or something. In another word, choice. It is similar with Al Ghalayaini (2009, p. 111) that in Arabic, 'ayy refers to question of choice.

However, there are some different concepts in meaning. When asking a concrete thing, the word is translated as 'apa/yang mana'. When asking about something refers to number or hour, it is translated as 'berapa'.

Table 4. Interrogative sentences of 'Ayy, Fì Ayy, Min Ayy'

\begin{tabular}{|c|c|c|c|c|}
\hline No & Arabic & Structure & Indonesian & Structure \\
\hline 1. & أَيّ خِدْمَة؟؟ & + أَيّ + N & $\begin{array}{l}\text { Ada perlu apa?/ } \\
\text { Apa yang bisa saya bantu? }\end{array}$ & $\begin{array}{l}\mathrm{N}+\text { Apa / } \\
\text { Apa + Part. + Aux } \\
+\mathrm{V}\end{array}$ \\
\hline 2. & أَيُّ فَصَلٍِ هَذَا؟ & + N & Musim apa ini? & $\mathrm{N}+$ apa \\
\hline 3. & أَيٌُّ مُعْجَمٍ تُرِيْدُ؟ & + أَيّ N & $\begin{array}{l}\text { Kamus apa/yang mana yang } \\
\text { kamu mau? }\end{array}$ & $\begin{array}{l}\mathrm{N}+\text { apa/ yang } \\
\text { mana }\end{array}$ \\
\hline 4. & 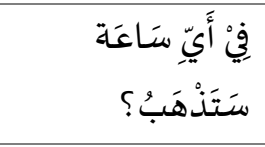 & $\begin{array}{l}\text { فِيْ أَيّيّ + N } \\
\text { (time) }\end{array}$ & $\begin{array}{l}\text { (Pada) jam berapa kamu akan } \\
\text { pergi? } \\
\text { (it refers to numeral of time) }\end{array}$ & $\begin{array}{l}\text { Prep. + N (time) } \\
+ \text { berapa }\end{array}$ \\
\hline 5. & فِيْ أَيِّ دَوْرِ الشَّقَّةَ؟ & $\begin{array}{l}\text { فئيْ أَيِّ + N } \\
\text { (place) }\end{array}$ & $\begin{array}{l}\text { Di lantai berapa } \\
\text { apartemennya? } \\
\text { (it refers to numeral of stage) }\end{array}$ & $\begin{array}{l}\text { Prep. + N (place) } \\
+ \text { berapa }\end{array}$ \\
\hline 6. & 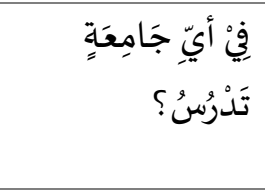 & $\begin{array}{l}\text { فِيْ أَيِّ + N } \\
\text { (place) }\end{array}$ & $\begin{array}{l}\text { Di universitas apa/ yang } \\
\text { mana kamu kuliah? } \\
\text { (it refers to university's name or } \\
\text { place) }\end{array}$ & $\begin{array}{l}\text { Prep. + N (place) } \\
+ \text { apa/ yang } \\
\text { mana }\end{array}$ \\
\hline 7. & 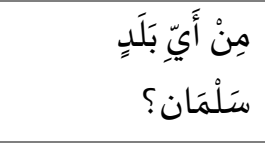 & $\begin{array}{l}\text { (place) } \\
\text { مِنْ أَيّْ + N }\end{array}$ & $\begin{array}{l}\text { Dari negara mana Salman } \\
\text { berasal? } \\
\text { (it refers to place) }\end{array}$ & $\begin{array}{l}\text { Prep. + N (place) } \\
+ \text { mana }\end{array}$ \\
\hline
\end{tabular}


Based on table 4, it shows that 'ayy, can be taken at the first sentence or middle. However, the question word in Indonesia is taken at the three positions; beginning, middle, and the end of sentence. Data (4), (5), (6) shows that 'ayy'is put between ' $f i^{\prime}$ word and object. While on data (7), 'ayy' is put between ' $m i n$ ' word and object. Furthermore, data (4), (5), (6), and (7) shows that ' $f i$ ayy and 'min ayy cannot be separated. While in Indonesia, ' $f i$ (di)' and ' $m i n$ (dari)' can be separated by other words. Then generally, those words are followed by $\mathrm{N}$. Therefore, different meaning selections like 'apa', 'yang mana', and 'berapa' are caused by the following word.

\section{Hal (هَلْ)}

The question word (هَلْ) is used to ask about something that allows the speaking partner to answer 'yes' or 'no'. This question has constant meaning, it is always translated as 'apakah' in Indonesian, either literally or grammatically. This similarity helps the learners to understand this concept more easily.

Table 5. Interrogative sentences of 'Hal'

\begin{tabular}{|c|c|c|c|c|}
\hline No & Arabic & Structure & Indonesian & Structure \\
\hline 1. & هَلْ أنْتَ طَالِبْ ؟ & هَل ه PP & $\begin{array}{l}\text { Apakah kamu seorang } \\
\text { pelajar? }\end{array}$ & Apakah + PP \\
\hline 2. & هَلْ هذا رَخيص ؟ & هَلْ + DP & Apakah ini murah? & Apakah + DP \\
\hline 3. & هَلْن تَذْهَبُ إلىلى & هَلْ + V & $\begin{array}{l}\text { Apakah kamu pergi ke } \\
\text { sekolah naik bis? }\end{array}$ & Apakah + PP + V \\
\hline 4. & هَلْ لَكِ أَحْ؟ & هَلْ + PP & $\begin{array}{l}\text { Apakah kamu mempunyai } \\
\text { saudara laki-laki? }\end{array}$ & Apakah + PP \\
\hline
\end{tabular}

From table 5, data (3) has different structure because Arabic verb has agglutinative PP. Therefore, ' $h a l$ can be followed by verb directly. Meanwhile, 'apakah' must be followed by PP before verb.

\section{Man (مَن)}

According to Al Ghalayaini (2009, p. 106) 'man' is used to ask someone as a subject. In Indonesian, that question word refers to the meaning of 'siapa'. In this regard, 'siapa' is used to ask something about noun of human, name, and somebody randomly as mentioned in KBBI. The word 'man' has constant meaning, it is always translated as 'siapa' in Indonesian, either literally or grammatically. The differences are occurred from the structure. Arabic has 
structure ' $\mathrm{man}^{\prime}+\mathrm{PP}$ and ' $\mathrm{man}^{\prime}+\mathrm{V}+\mathrm{O}$. While, Indonesian has structure 'siapa' $+\mathrm{PP}$ and 'siapa'+ part. $+\mathrm{V}+\mathrm{O}$.

Table 6. Interrogative sentences of 'Man'

\begin{tabular}{|c|c|c|c|c|}
\hline No & Arabic & Structure & Indonesian & Structure \\
\hline 1. & مَنْ هُوَ؟ & + مَنْ PP & Siapa dia? & Siapa + PP \\
\hline 2. & مَنْ فَتَحَ الْبَابَ؟ & مَنْ + V + O & $\begin{array}{l}\text { Siapa yang membuka } \\
\text { pintu? }\end{array}$ & $\begin{array}{l}\text { Siapa + Part. + V + } \\
\text { O }\end{array}$ \\
\hline 3. & مَنْ يُخْبِرِكَكَ؟ & مَنْ $+V+O$ & $\begin{array}{l}\text { Siapa yang } \\
\text { memberitahumu? }\end{array}$ & $\begin{array}{l}\text { Siapa + Part. + V + } \\
\text { O }\end{array}$ \\
\hline
\end{tabular}

From table 6, data (2) and (3) require participle between 'siapa' and verb in Indonesian, however 'mar' in Arabic does not require it. The word 'man' can be followed by verb directly.

\section{Ayna (أيْنَ)}

The question word (أيَنَ) is translated as 'di mana' which is used to ask a question related to places. Both in Arabic and Indonesian, there is no difference in meaning, but the structure occurs difference as ayna $+\mathrm{V}$; ila ayna $+\mathrm{V}$. While Indonesian has structure di mana + PP; ke mana + PP. That is because Arabic verb has agglutinative PP (morphological system). Consider examples in table 7.

Table 7. Interrogative sentences of 'Ayna'

\begin{tabular}{|c|c|c|c|c|}
\hline No & Arabic & Structure & Indonesian & Structure \\
\hline 1. & أَيْن هو؟ & أَيْن + PP & Di mana dia? & Di mana + PP \\
\hline 2. & أَيْنَ قهوتك؟ & PoP & Di mana kopimu? & Di mana + PoP \\
\hline 3. & أَيْنَ جَامِعَةُ أُُِّم القُرىى؟ & N أَيْن N N & $\begin{array}{l}\text { Di mana Universitas } \\
\text { Umm al Qura? }\end{array}$ & Di mana + N \\
\hline 4. & أَيْنَ تَسْكُنُ؟ & ا أَيْن + V & $\begin{array}{l}\text { Di mana kamu } \\
\text { tinggal? }\end{array}$ & Di mana + PP \\
\hline 5. & إلَّى أَيْنَ تَذْهَبُ؟ & إلَى أَيْنَ + V & $\begin{array}{l}\text { Ke mana kamu akan } \\
\text { pergi? }\end{array}$ & Ke mana + PP \\
\hline 6. & مِنْ أَيْنَ أَنْتَ قَادِم؟ & م مِنْ أَيْنَ + PP & Dari mana kamu? & Dari mana + PP \\
\hline
\end{tabular}

Data (5) and (6) show that 'aynd can be put at the middle of sentence. Either put it between 'ila' and verb or ' $\mathrm{min}$ ' and PP.

\section{Matā (مَ)}

The question word (مَتَ) is used to ask a question about time. Al Ghalayaini (2009, p. 109) mentions that 'matā' is related to question of time such as past, present, and future. In Indonesian, this question word is translated as 'kapan'. 
Both of the them have no difference in meaning, but it occurs in structure. The comparison between matā $+\mathrm{V}$ and kapan + PP. It is because Arabic verb has agglutinative PP as in table 8.

Table 8. Interrogative sentences of 'Matā'

\begin{tabular}{|c|c|c|c|c|}
\hline No & Arabic & Structure & Indonesian & Structure \\
\hline 1. & مَتَى سَيَاتْتِيْ؟ & مَتَى + V & $\begin{array}{l}\text { Kapan dia akan } \\
\text { tiba? }\end{array}$ & Kapan + PP \\
\hline 2. & مَتَى الْعُطُلْةَ & + مَتَى + N & Kapan liburan? & Kapan + N \\
\hline 3. & مَتَى اسنتَيَتِظِتَتَ مِنَ النَّوْم؟؟ & مَتَى + V & $\begin{array}{l}\text { Kapan kamu } \\
\text { bangun tidur? }\end{array}$ & Kapan + PP \\
\hline
\end{tabular}

\section{Limādzā (مأمَ)}

The question word (لمَاذًا) in Indonesian is translated as 'mengapa'. This question word is used to ask for causes, reasons, or actions. The use of both languages is similar. Therefore, this similarity is advantageous for the learners. The examples of this question word are in table 9.

Table 9. Interrogative sentences of 'Limādzā'

\begin{tabular}{|c|c|c|c|c|}
\hline No & Arabic & Structure & Indonesian & Structure \\
\hline 1. & لمِ لمَذَا ذَهَبَ إلَّى مِصْرَ؟ & 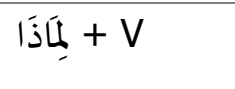 & $\begin{array}{l}\text { Mengapa dia pergi ke } \\
\text { Mesir? }\end{array}$ & Mengapa + PP + V \\
\hline 2. & لِمَاذَا ثوبك صغير ؟ & 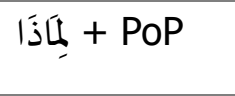 & $\begin{array}{l}\text { Mengapa bajumu } \\
\text { kecil? }\end{array}$ & Mengapa + PoP \\
\hline
\end{tabular}

\section{Kayfa (كَيْفَ)}

The question word 'kayfa' is translated as 'bagaimana' and 'apa' in Indonesian. According to Al Ghalayaini (2009, p. 110), 'kayfa' is used to ask about situation. Meanwhile, as mentioned in KBBI, the word 'bagaimana' is used to ask method, result of action, and opinion.

Table 10. Interrogative sentences of 'Kayfa'

\begin{tabular}{|c|c|c|c|c|}
\hline No & Arabic & Structure & Indonesian & Structure \\
\hline 1. & كَيْفَ حَالُك ؟ & كَيْفَ + N & $\begin{array}{l}\text { Apa kabar? / } \\
\text { Bagaimana kabarmu? }\end{array}$ & $\begin{array}{l}\text { Apa }+\mathrm{N} \\
\text { Bagaimana + PoP }\end{array}$ \\
\hline 2. & كَيْفَ تَذْهَبُ إلََى المِدِينَةَّ؟ & كَيْفَ + V & $\begin{array}{l}\text { Bagaimana/ Dengan apa } \\
\text { kamu pergi ke Madinah? }\end{array}$ & $\begin{array}{l}\text { Bagaimana/ } \\
\text { dengan apa + PP }\end{array}$ \\
\hline 3. & كَيْفَ الْجَوُو فِي لَنْدن ؟ & كَيْفَ N N N & $\begin{array}{l}\text { Bagaimana cuaca di } \\
\text { London? }\end{array}$ & Bagaimana + N \\
\hline 4. & كَيْنَفَ تَقْضِي الوقتَ فِيْ & كَ كَيْفَ + V & $\begin{array}{l}\text { Apa saja yang kamu } \\
\text { lakukan di Jeddah? }\end{array}$ & $\begin{array}{l}\text { Apa saja + Part. } \\
\text { + PP }\end{array}$ \\
\hline
\end{tabular}


Based on table 10, if data (4) is translated literally, it means 'Bagaimana kamu menghabiskan waktu di Jeddah?'. Although grammatically correct, the question with this sentence is uncommon in Indonesian. Thus, it is more properly translated as 'Apa saja yang kamu lakukan di Jeddah?'.

\section{Kam, Bikam (كَمْ، بحَمْ}

The question word (كَمَ) is translated as 'berapa' in Indonesian. Al Ghalayaini (2009, p. 111) mentions that ' $k a m$ ' is related to question of quantity. Meanwhile, as mentioned in KBBI, the word 'berapa' refers to question word about quantity, size, price, time, and unit of measure.

Table 11. Interrogative sentences of 'Kam, Bikam'

\begin{tabular}{|c|c|c|c|c|}
\hline No & Arabic & Structure & Indonesian & Structure \\
\hline 1. & كَمْ وَزْنُك ؟ & + كَمْ PoP & $\begin{array}{l}\text { Berapa berat } \\
\text { badanmu? }\end{array}$ & $\begin{array}{l}\text { Berapa + N + } \\
\text { PoP }\end{array}$ \\
\hline 2. & كَمْ عُمْرُكَ & كَ SoP & Berapa usiamu? & Berapa + PoP \\
\hline 3. & كَمْ دَرَجَةُ الْحَرَارَة فِيْ لَنْدَن؟؟ & كَم + N & $\begin{array}{l}\text { Berapa derajat (suhu) } \\
\text { di London? }\end{array}$ & Berapa $+\mathrm{N}$ \\
\hline 4. & كَمْ غُرْفَةَة فِيْ بَيْتِكَ؟ & S + N N & $\begin{array}{l}\text { Berapa (jumlah) kamar } \\
\text { di rumahmu? }\end{array}$ & Berapa + N \\
\hline 5. & كَمْ وَجْبَةَ تَأْكُكُ فِي الَيَوْمِ؟ & S كَم + Adv. & $\begin{array}{l}\text { Berapa kali kamu } \\
\text { makan dalam sehari? }\end{array}$ & Berapa + Adv. \\
\hline 6. & كَمْ سَاعَاة تَعْمَلُ فِي اليَوْم؟ & كَمْ + Adv. & $\begin{array}{l}\text { Berapa jam kamu } \\
\text { bekerja dalam sehari? }\end{array}$ & Berapa + Adv. \\
\hline 7. & كَم السَّاعَةُ الآن؟ & كَمْ + Adv. & Jam berapa sekarang? & $\mathrm{N}+$ berapa \\
\hline 8. & 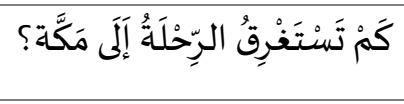 & + كَمْ V V V & $\begin{array}{l}\text { Berapa jam perjalanan } \\
\text { ke Makkah? }\end{array}$ & Berapa + \\
\hline 9. & كَمْ رِيَالاً المَلْلُؤبْ؟ & كَمْ + N & Berapa totalnya? & Berapa + N \\
\hline 10. & بِكَمِ الثَّوْبُ ؟ & N + بِكَمِ N & $\begin{array}{l}\text { Berapa harga } \\
\text { bajunya? }\end{array}$ & Berapa \\
\hline
\end{tabular}

From table 11, data (9) and (10) both refer to the question of price. However, كَمْ is used if followed by a currency unit. The question word بحَّ is used when followed by the object.

\section{Problems with Interrogative Sentences}

In attempt to adapt with $\mathrm{L} 2$ while speaking, learner may seek support from the mother tongue or foreign language. In this regard, foreign language communication may involve wrong analogies (Lekova, 2010, p. 323). The issue of language interference is directly related to the mother tongue which has established the learners' language world and has introduced them with the problem of language phenomena (Lekova, 2010, p. 324). 
The problems of language phenomena are caused by some differences form between L1 and L2. In this study, it is categorized into three types; (a) problems in forming interrogative sentences or selecting the right question words in L2; (b) problems in translating question words from L2 to L1; and (c) problems in understanding L2 questions and giving answers.

\section{Problems in The Use of Questions}

In making interrogative sentences, not all question words in Indonesian have exact equivalence with the question words in Arabic. Errors in using question words can occur when the learners use L1 without learning the meaning of each interrogative sentence or the habits of L2 user community as in table 12.

Table 12. Problems in the Use of Questions

\begin{tabular}{|c|c|c|}
\hline $\begin{array}{l}\text { Uncommon } \\
\text { (Incorrect) }\end{array}$ & Common (Correct) & Differences \\
\hline \multirow[t]{2}{*}{ مَنْ إسسْمُكَك؟ } & مَاساستمُكَ؟َ؟ & (L2) = Siapa (L1) \\
\hline & Siapa namamu? & \\
\hline \multirow[t]{2}{*}{ مَا الأَطْعِمَة تُفَضِيّل؟؟ } & أيَّ الأطُعْمَة تُفضِّل؟ & $L^{\prime}(L 2)=A p a(L 1)$ \\
\hline & Apa makanan favoritmu? & \\
\hline \multirow[t]{2}{*}{ كَيْفَ تَشْعُرُ؟ } & 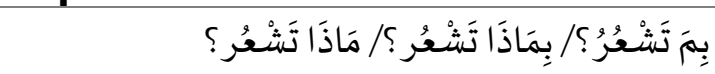 & (L2) = Bagaimana \\
\hline & Bagaimana perasaanmu? & (L1) \\
\hline \multirow[t]{2}{*}{ كَمْ رَقْمُمُ الْجَوَّالِ؟ } & مَا رَفْمُ الْجَوََالِ؟ & كَ) = Berapa (L1) \\
\hline & Berapa nomor handphonemu? & \\
\hline \multirow[t]{4}{*}{ كَمْ وَزَنْ زَيَنَبَب؟ } & مَا وَزنْن زَيَنَبُ؟؟ & كَ) = Berapa (L1) \\
\hline & Berapa berat badan Zainab? & \\
\hline & كَمْ وَزْنْكَكَ؟ & \\
\hline & Berapa berat badanmu? & \\
\hline \multirow[t]{2}{*}{ كَمْ فِيْ دَوْرِ الشَّقََّّ؟ } & فِيٌْ أَيِّ دَوٍٍْ الشَّقَّةَ؟ & (L2) = Berapa (L1) \\
\hline & Di lantai berapa apartemennya? & \\
\hline كَمْ سَاعَةًَ تَذْهَبُ إلَّى & 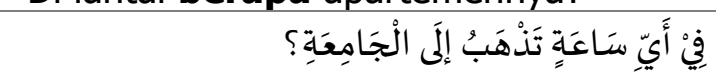 & كَ) = Berapa (L1) \\
\hline الْجَامِعَةِ؟؟ & Jam berapa kamu pergi ke universitas? & \\
\hline \multirow[t]{2}{*}{ كَمْ تَمَنْ الثَّوْبَ؟ } & بِكَمْ الثَّوْب؟ & كَمَ (L2) = Berapa (L1) \\
\hline & Berapa harga bajunya? & \\
\hline \multirow[t]{2}{*}{ بِمَاذَا كُلِيَّةٍ تَدْرُسُ } & 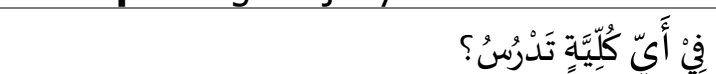 & $ب(\mathrm{~L} 2)=\mathrm{Di}(\mathrm{L} 1)$ \\
\hline & Kamu belajar di jurusan apa? & مَاذًا (L2) = Apa (L1) \\
\hline \multirow[t]{2}{*}{ بِمَاذَا جَامِعَةٍة تَدْرُسُ؟ } & 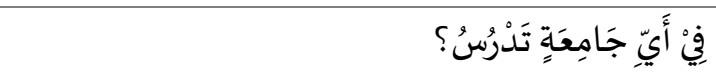 & $\stackrel{\varphi}{(L 2)}$ = Di (L1) \\
\hline & Kamu belajar di kampus apa? & (L2) = Apa (L1) \\
\hline \multirow[t]{2}{*}{ مِنْ أَيْنَ بَلَدِ سَلْمَان؟ } & مِنْ أَيَّ بَلَدِ سَلمان؟؟ & (L2) = Dari mana \\
\hline & Salman dari negara mana? & (L1) \\
\hline
\end{tabular}




\section{Problems in The Translation of Interrogative Sentences from L2 to L1}

Errors in translating interrogative sentences can occur as a result of the learners translating L2 into L1 using L2 grammar and ignoring L1 grammar and habits. In addition, when learners translated $\mathrm{L} 2$ to $\mathrm{L} 1$ by word to word translation, it causes unacceptable sentence in L1. Moreover, it may occur different meaning like examples in table 13.

Table 13. Problems in Translation of Interrogative Sentences from L2 to L1

\begin{tabular}{|c|c|c|}
\hline Question & Uncommon & Common \\
\hline مَاذَا تَأْكُكُ فِيْ الفَطُوْرِ؟ & $\begin{array}{l}\text { Apa yang kamu makan di pagi } \\
\text { hari? }\end{array}$ & Kamu sarapan apa? \\
\hline مَاذَا تَأْكُلْ فِيْ الغَدَاءِ؟ & $\begin{array}{l}\text { Apa yang kamu makan di siang } \\
\text { hari? }\end{array}$ & $\begin{array}{l}\text { Kamu makan siang dengan } \\
\text { apa? }\end{array}$ \\
\hline مَاذَا تَأْكُلُ فِيْ العَشَاءِ؟ & $\begin{array}{l}\text { Apa yang kamu makan di malam } \\
\text { hari? }\end{array}$ & $\begin{array}{l}\text { Kamu makan malam } \\
\text { dengan apa? }\end{array}$ \\
\hline مَاذَا تَطْلْبِيْنَ مِنَ الطُعَّام؟ & $\begin{array}{l}\text { Apa yang kamu cari dari } \\
\text { makanan? }\end{array}$ & $\begin{array}{l}\text { Kamu mencari makanan } \\
\text { apa? }\end{array}$ \\
\hline كَيْفَ تَقْضِي الوقتَ فِيْ جَدَّة؟ & $\begin{array}{l}\text { Bagaimana kamu menghabiskan } \\
\text { waktu di Jeddah? }\end{array}$ & $\begin{array}{l}\text { Apa saja yang kamu } \\
\text { lakukan di Jeddah? }\end{array}$ \\
\hline
\end{tabular}

\section{Problems in Answering Questions}

Errors in understanding questions lead the learners to give less precise answers in L2. This can occur due to a lack of the learners' understanding of the language habits of the L2 user community as in table 14 .

Table 14. Problems in the Use of Questions

\begin{tabular}{|c|c|c|}
\hline Question & Incorrect & Correct \\
\hline مَاذَا تَعْمَلُ أنْتَ؟ & اََنَا اََقْرَأُ كِتَابًا & أَعْمَلُ مُهَنْدِدًِا \\
\hline مَاذَا سَتَتَعْمَلُ بَعْدَ الدِّرَاسَةَّ؟ & سَأذذْهَبُ إلَى الْمَكْتَبَة & سَأَعْمَلُُ طَيَّارًا إن شَاء الله \\
\hline مَاذَا سَتَتْفَدَلُ بَعْدَ الدِّرَاسَةَّ؟ & اَنَا سَأَكُونُ طَبِيْبًا & سَأَقَرْأُ مَجَلَلًَة \\
\hline
\end{tabular}

\section{CONCLUSIONS}

According to the research, there are three conclusions that can be drawn, such as; (a) CA is a method to find similarities and differences between Arabic (L2) and Indonesian (L1). The equivalence of the question words between the two languages are found lexically. On the contrary, the difference forms and functions between them are found grammatically. It means that the following word after question word may result different functions. Similarity concept between them is many shown on matā, ayna, limādzā, and hal. Meanwhile, differences between both of them are shown on $m \bar{a}$, man, ayy, and kayfa; (b) Question words in Arabic can be put at the beginning and middle of the sentence. 
As for in Indonesian, the question word is put either at the beginning, middle, or the end of the sentence; (c) Problems in making interrogative sentence either from Arabic into Indonesian or Indonesian into Arabic can be caused by difference systems between them, as a result, it occurs errors in the use of question, errors in translating interrogative sentence, and errors in understanding question.

This research has implication in answering similarities and differences between Arabic and Indonesian interrogative sentence. Therefore, it can be used by teacher to design appropriate material for Teaching Arabic as a Foreign Language (TAFL). In addition, knowing this CA for students will make them easy to understand and practice. Finally, research opportunity about CA involving Arabic and Indonesian is still opened widely. There are many areas very likely to be analyzed which is hoped giving impact for TAFL in Indonesia especially.

\section{BIBILIOGRAPHY}

Adila, W. (2019). 'A Written Grammatical Error Analysis of Second Year Students of Arabic', Arabi: Journal of Arabic Studies, 4(1), 31-44. DOI: http://dx.doi.org/10.24865/ajas.v4i1.141.

Al Ajlouny, M. (2007). 'Contrastive Analysis and Diglossia', International Journal of Arabic-English Studies (IJEAS), Vol. 8

Al Fauzan, A.I., Husain, M.T., Fadhil, M.A.K.M. (2003). Al 'Arabiyyah Baina Yadaik 1. Riyadh: Al Maktab Ar Ra'isy Al 'Arabiyyah lil Jami' Al Waqful Islamiy.

Al Ghalayini, M. (2009). Jāmi' ad Durūs al 'Arabiyyah. Beirut: Dar al Kutub al 'Ilmiyah.

Al Khresheh, M. H. (2016). 'A Review Study of Contrastive Analysis Theory', Journal of Advances in Humanities and Social Sciences, 2 (6), 330-338. DOI: http://doi.org/10.20474/jahss-2.6.5.

Badan Pengembangan Bahasa dan Perbukuan. (2019). Kamus Besar Bahasa Indonesia (KBBI). Retrieved November 23, 2019, from https://kbbi.kemdikbud.go.id

Brosh, H. Y. (2019). 'Arabic language-learning strategy preferences among undergraduate students', Studies in Second Language Learning and Teaching, 9(2), 351-377. DOI: https://doi.org/10.14746/ssllt.2019.9.2.5.

Dost, E. N. (2017). 'A Review of Contrastive Analysis Hypothesis with a Phonological and Syntactical View: A Cross Linguistic Study', The Buckingham of Language and Linguistics, 10(1), 32-41. DOI: http://dx.doi.org/10.5750/bjll.v10i0.1482. 
Els, T. V., Bongaerts, T., Extra, G., Van Os, C., \& Van Dieten, A. M. J. (1991). Applied Linguistics and the Learning and Teaching of Foreign Languages. Great Britain: Edward Arnold Publishers.

El Majid, W.A.E.A \& Ahmed, M.A. (2016). 'A Contrastive Analysis of English and Arabic Translation Problems', Journal of Humanities, 17 (4), 131-144.

Enein, Sameh, A. (n.d.) 'Language and Cultural Diplomacy: Arabic', Ambassador Speech on UN Library Talks Geneva. Retrieved November 23, 2019, from https://www.unog.ch/unog/website/library.nsf.

Firdaus, M. (2019). 'Problems in Expressing Arabic Language of Indonesian Students at Khartoum International Institute for Arabic Language', Izdihar: Journal of Arabic Language Teaching, Linguistics, and Literature, 2 (1), 35-52. DOI: https://doi.org/10.22219/jiz.v2i1.7588.

Fauziati, E. (2014). 'Contrastive Analysis, Transfer Analysis, Error Analysis, and Interlanguage: Four Concepts One Goal', ADJES: Ahmad Dahlan Journal of English Studies, 1 (1-2), 9-21.

Fatoni, A. (2019). 'Arabic Learning for Academic Purposes', Izdihar : Journal of Arabic Language Teaching, Linguistics, and Literature, 2 (2), 139-152. DOI: https://doi.org/10.22219/jiz.v2i2.10096.

Hasan, R. (2018). 'Implikasi Analisis Kontrastif Kalimat Bahasa Arab dan Bahasa Indonesia dalam Meningkatkan Pemahaman Siswa', Jurnal Shaut Al 'Arabiyah, 6 (1), 105-113. DOI: https://doi.org/10.24252/saa.v6i1.4801

Huda, K. (2019). 'Perbandingan Struktur Obyek pada Bahasa Arab dan Bahasa Indonesia: Penelitian Analisis Kontrastif dalam Koran Al-Jazirah dan Koran Tempo', Al Fathin: Jurnal Bahasa dan Sastra Arab, 2 (1), 111-120. DOI: https://doi.org/10.32332/al-fathin.v2i2.1546

Khansir, A. A. (2012) 'Error Analysis and Second Language Acquisition', Theory and Practice in Language Studies, 2 (5), 1027-1032. DOI: https://doi.org/10.4304/tpls.2.5.1027-1032.

Lado, Robert. (1957). Linguistics Across Cultures. Ann Arbor: The University of Michigan Press.

Lekova, B. (2010). 'Language Interference and Methods of Its Overcoming in Foreign Language Teaching', Trakia Journal of Sciences, 8 (3), 320-324.

Lindawati. (2016). 'Indonesian Interrogative Sentences: a Study Forms and Function', Jurnal Humaniora, 28 (3), 348-357. DOI: https://doi.org/10.22146/jh.22289.

Masqon, D. (2018). 'Daur al Lughah al Arabiyyah fi 'Ashr al 'Aulamah wa Tathbīqihā fi Tathwīr al 'Ulūm', Izdihar : Journal of Arabic Language Teaching, Linguistics, and Literature, 1 (1), 25-64. DOI: https://doi.org/10.22219/izdihar.v1i1.6562. 
Momani, M. M. \& Al Taheer, A. Muneer. (2015). 'A Contrastive Analysis of English and Arabic from a Syntactical Perspective', Canadian Open English and Literature Journal, 2 (1), 1-8.

Nikmah, K. (2019). 'Meaning Variations of Qāla (قال) in Indonesian Language,' Izdihar: Journal of Arabic Language Teaching, Linguistics, and Literature, 2 (2), 77-100. DOI: https://doi.org/10.22219/jiz.v2i2.9909.

Nur, T. (2016). 'Analisis Kontrastif dalam Studi Bahasa', Arabi: Journal of Arabic Studies, 1 (2), 64-74. DOI: https://doi.org/10.24865/ajas.v1i2.11.

Omar, T. (2017). 'Culture and Second Language Acquisition: Arabic Language as A Model', European Scientific Journal, 13 (2), 159-166. DOI: https://doi.org/10.19044/esj.2016.v13n2p159.

Qodri, M. (2019). 'Lexical Phenomenon in Linguistics Theories', Izdihār: Journal of Arabic Language Teaching, Linguistics, and Literature, 2 (1), 1-16. DOI: https://doi.org/10.22219/jiz.v2i1.8326.

Rabab'ah, G. \& Bulut, D. (2007). 'Compensatory Strategies in Arabic as A Second Language', Poznań Studies in Contemporary Linguistics, 43(2), 2007, 83106. DOI: https://doi.org/10.2478/v10010-007-0020-5.

Rustipa, K. (2011). 'Contrastive Analysis, Error Analysis, Interlanguage, and the Implication to Language Teaching', Ragam: Jurnal Pengembangan Humaniora, 11 (1), 16-22.

Sabbah, S. S. (2015). 'Negative Transfer: Arabic Language Interference to Learning English', Arab World English Journal, Special Issue (4), 269-288. http://dx.doi.org/10.2139/ssrn.2844015.

Saidah. (2011). 'Studi Kontrastif antara Adawat al Istifham dalam Bahasa Arab dan Question Words dalam Bahasa Inggris', Unpublished Master's theses. Universitas Islam Negeri Alauddin Makassar.

Parera, J. D. (1997). Linguistik Edukasional. Jakarta: Penerbit Erlangga.

Umami, M. (2015). 'A Contrastive Analysis of Interrogative Sentences in English and Indonesian', Register Journal, 8 (2), 151-260. DOI: https://doi.org/10.18326/rgt.v8i2.151-162. 